10-1-1999

\title{
Enantioselective Synthesis of Dual Serotonergic Azanoradamantane SC-52491
}

Daniel Becker

Loyola University Chicago, dbecke3@luc.edu

Robert K. Husa

Alan E. Moormann

Clara I. Villamil

Follow this and additional works at: https://ecommons.luc.edu/chemistry_facpubs

Part of the Chemistry Commons

Author Manuscript

This is a pre-publication author manuscript of the final, published article.

\section{Recommended Citation}

Becker, Daniel; Husa, Robert K.; Moormann, Alan E.; and Villamil, Clara I.. Enantioselective Synthesis of Dual Serotonergic Azanoradamantane SC-52491. Tetrahedron Letters, 55, 40: , 1999. Retrieved from Loyola eCommons, Chemistry: Faculty Publications and Other Works, http://dx.doi.org/10.1016/ S0040-4020(99)00680-8

This Article is brought to you for free and open access by the Faculty Publications and Other Works by Department at Loyola eCommons. It has been accepted for inclusion in Chemistry: Faculty Publications and Other Works by an authorized administrator of Loyola eCommons. For more information, please contact ecommons@luc.edu. cc) (i) $\Theta$

This work is licensed under a Creative Commons Attribution-Noncommercial-No Derivative Works 3.0 License. (c) 1999 Elsevier 


\title{
ENANTIOSELECTIVE SYNTHESIS OF DUAL 5-HT $/ 5-\mathrm{HT}_{3}$ SEROTONERGIC AZANORADAMANTANE SC-52491
}

\author{
Daniel P. Becker*a ${ }^{\mathrm{a}}$, Robert K. Husa ${ }^{1}$, Alan E. Moormann ${ }^{\mathrm{b}}$, \\ Clara I. Villamil ${ }^{\text {, }}$, Daniel L. Flynn ${ }^{2}$ \\ Department of Medicinal Chemistry, Searle Research \& Development, \\ a4901 Searle Parkway, Skokie, IL 60077 \\ '700 Chesterfield Village Parkway, St. Louis, MO 63198
}

\begin{abstract}
A racemic synthesis of azanoradamantane ( \pm )-3 was accomplished via Yamamoto's MAD-catalyzed Diels-Alder protocol. Subsequently, a scalable asymmetric synthesis of azanoradamantane benzamide SC-52491 was carried out employing Helmchen's asymmetric Diels-Alder methodology to construct all four contiguous asymmetric centers with the correct relative stereochemistry and in $99.3 \%$ e.e.
\end{abstract}

Keywords: asymmetric synthesis; Diels-Alder ; serotonin; 5-hydroxytryptamine; 5-HT; azanoradamantane

Pharmaceutical companies are advancing an increasing number of enantiomerically pure drugs ${ }^{1}$ in order to maximize potency and selectivity, and to eliminate the complications which may arise from the presence of a less active or inactive stereoisomer. The asymmetric Diels-Alder ${ }^{2}$ reaction is a powerful synthetic method for the construction of non-racemic pharmacologically active agents.

In earlier communications ${ }^{3}$ we disclosed a series of azaadamantane and azanoradamantane benzamides, including the potent serotonin 5- $\mathrm{HT}_{4}$ agonist/5- $\mathrm{HT}_{4}$ antagonist $\mathbf{S C - 5 2 4 9 1}$, which has an $\mathrm{EC}_{50}$ of $51 \mathrm{nM}$ in the 5$\mathrm{HT}_{4}$ tunica muscularis mucosae assay ${ }^{4}$ and a $\mathrm{K}_{\mathrm{i}}$ of $1.2 \mathrm{nM}$ at the 5-HT receptor. $^{5}$ SC-52491 was chosen for further study of its gastrointestinal prokinetic activity and its antiemetic activity based on its potent 5- $\mathrm{HT}_{4}$ agonism and its tandem property of potent 5- $\mathrm{HT}_{3}$ antagonism, respectively, combined with its exceptional selectivity versus other monoamine receptors. ${ }^{6}$ It is orally active and exhibits potent prokinetic activity and antiemetic activity in vivo, and compares very favorably with the marketed prokinetic cisapride. SC-52491 is the more active enantiomer with respect to both $5-\mathrm{HT}_{4}$ and $5-\mathrm{HT}_{3}$ activity, as it is $70 \mathrm{X}$ as potent as $\mathbf{S C - 5 2 4 9 0}$ in the functional 5- $\mathrm{HT}_{4}$ assay, and it is $3 \mathrm{X}$ as potent in its binding to the $5-\mathrm{HT}_{3}$ receptor.

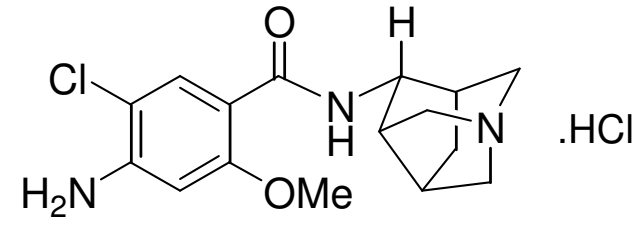

SC-52491<smiles>COc1cc(N)c(Cl)cc1C(=O)NC1C2CC3CC1N3C2</smiles>

SC-52490

\footnotetext{
*Corresponding author email: daniel.p.becker@monsanto.com

${ }^{1}$ Current address: MDL Information Systems, Inc., 3 Westbrook Corporate Center, Westchester, IL 60154

${ }^{2}$ Current address: One Amgen Center, Thousand Oaks, CA 91320-1799
} 
We required a scalable asymmetric synthesis of SC-52491, which contains four contiguous asymmetric centers. Our previous ${ }^{7}$ synthetic route (Scheme 1) employed a reductive Pauson-Khand reaction ${ }^{8}$ which was ideal for small-scale synthesis, and a late-stage resolution which provided us with both enantiomers for biological evaluation, but these procedures are not easily scalable. The previous synthesis of SC-52491 did employ a very efficient closure to the azanoradamantane ring system [(-)-1 to (+)-2], and we hoped that we could utilize a similar cyclization in our new synthetic strategy. We also wanted to eliminate chlorinated solvents from the synthesis and to simplify or eliminate any chromatographic purifications.

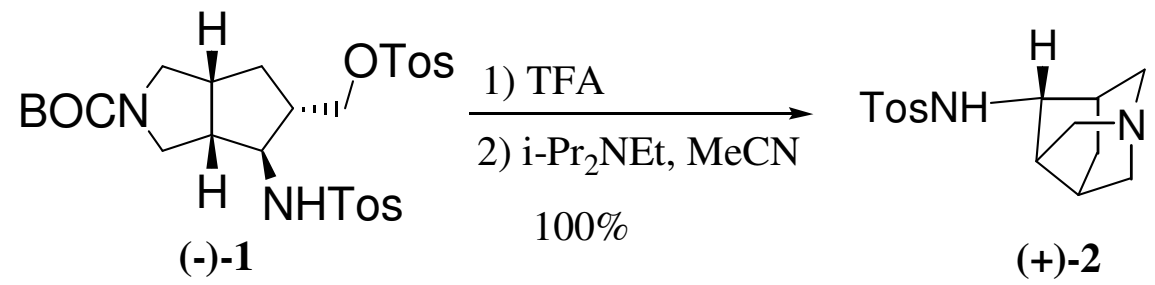

\section{Scheme 1}

We envisioned a new approach based on the retrosynthetic analysis shown in Scheme 2, wherein the azanoradamantane $\mathbf{3}$ would be formed in one step from a tetrasubstituted cyclopentane $\mathbf{4}$ via a tandem cyclization involving $\mathrm{SN}_{2}$ displacement of suitable leaving groups $(\mathrm{X})$ by the primary amine. One of the two cyclizations is the same as the efficient cyclization employed in our previous synthetic approach. The tetrasubstituted cyclopentane $\mathbf{4}$ would then be derived from oxidative cleavage of a rigid norbornene $\mathbf{5}$, in which the four contiguous asymmetric centers could be easily defined and prepared via an asymmetric Diels-Alder reaction.

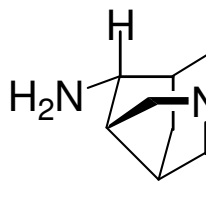

3

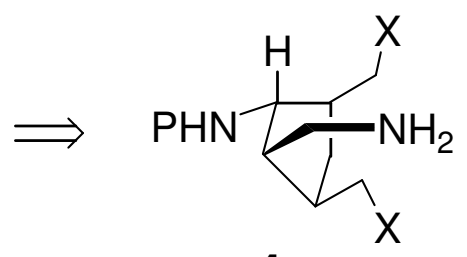

4

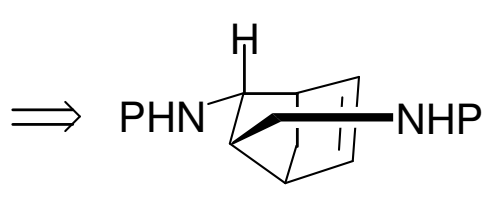

5

\section{Scheme 2}

We first employed Yamamoto's MAD-catalyzed Diels-Alder reaction ${ }^{9}$ to prepare norbornene $( \pm)-7$ (Scheme 3). This approach assembles the four requisite stereocenters in their proper relative orientation, albeit in racemic fashion. We originally hoped to employ an early-stage resolution or to employ a chiral Lewis acid catalyst in the Diels-Alder reaction to obtain the correct absolute configuration of the four stereocenters. Ultimately the Yamamoto approach allowed us to explore various means of installing functionality to provide the bridgehead nitrogen and the amino substituent of aminoazanoradamantane 3. As per Yamamoto's protocol, cyclopentadiene is reacted with tert-butyl methyl fumarate $6^{10}$ with MAD catalysis to afford the Diels-Alder 
adduct ( \pm )-7 in high yield and excellent diastereoselectivity (98:2). The esters are easily differentiated by cleaving the tert-butyl ester with trifluoroacetic acid to afford carboxylic acid $( \pm)-7$. We proceeded from Yamamoto's intermediate $( \pm)-7$ with a Curtius rearrangement to install the exo-amino substituent protected as the benzyl carbamate in compound $(\mathbf{\pm})-\mathbf{8}$. Lithium borohydride reduction gave the endo hydroxymethyl derivative ( $( \pm)-9$.

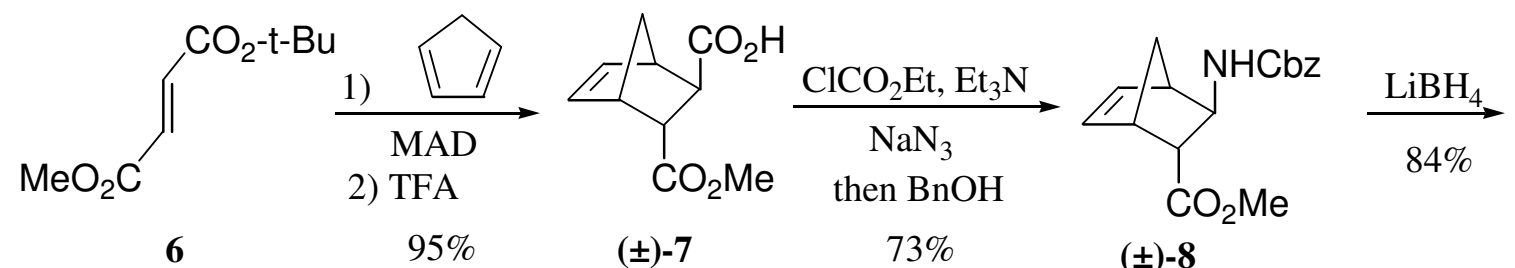

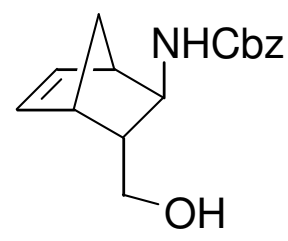

(土)-9

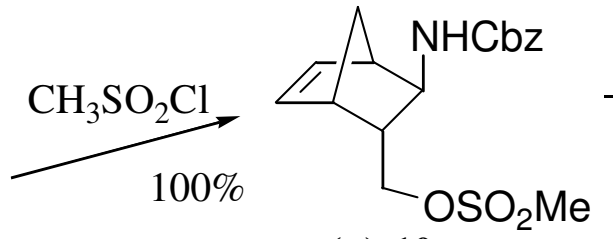

( \pm -10

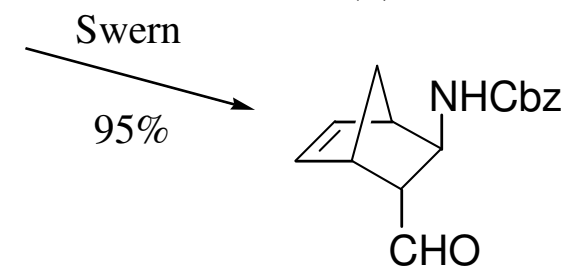

(士)-12

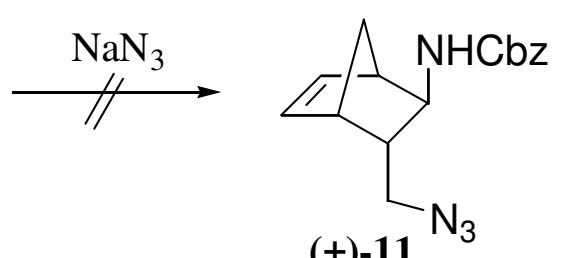

(士)-11

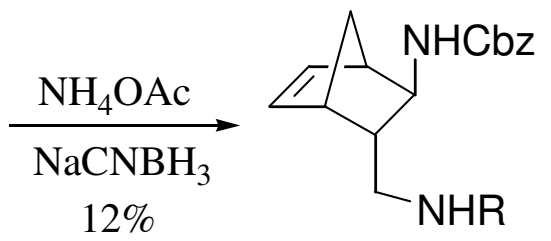

$$
12 \%
$$$$
\begin{aligned}
& \mathrm{BOC}_{2} \mathrm{O}( \pm)-13 \mathrm{R}=\mathrm{H} \\
&( \pm)-14 \mathrm{R}=\mathrm{BOC}
\end{aligned}
$$
$88 \%$

\section{Scheme 3}

The alcohol ( \pm )-9 was converted to the mesylate $( \pm)-\mathbf{1 0}$ in quantitative yield, but the mesylate was unexpectedly resistant toward displacement by azide. Treatment with sodium azide in a variety of solvents, with or without added sodium iodide present in the reaction mixture gave no desired product. Only starting material was observed until the temperature was raised sufficiently for consumption of starting material, at which point the norbornene bicyclic system was also destroyed, presumably via a retro-Diels-Alder reaction. To overcome this problem, alcohol $( \pm)-9$ was oxidized to the aldehyde $( \pm)-12$ in $95 \%$ yield with no evidence of epimerization. Reductive amination of the aldehyde with ammonium acetate gave the desired primary amine $( \pm)-13$, but in consistently low yields, along with significant quantities of secondary amine by-product. Attempts to optimize the reductive amination of aldehyde ( \pm )-12 were unsuccessful. The amine $( \pm)-\mathbf{1 3}$ was protected as the BOC derivative $( \pm)-14$. Despite the inefficient reductive amination, sufficient quantities of the 
BOC-protected amine ( \pm -14 were obtained to continue validation of the Diels-Alder approach to aminoazanoradamantanes.

Ozonolysis of the norbornene $( \pm)-14$ followed by workup with sodium borohydride gave the diol ( \pm )-15 in $27 \%$ yield (Scheme 4). Diol ( \pm )-15 was converted to the azanoradamantane $( \pm)-16$ by a sequence involving bis-tosylation, trifluoroacetic acid removal of the BOC protecting group, and subsequent treatment with diisopropylethylamine, as in the conversion of (-)-1 to (+)-2. We were confident at this point that we had obtained the desired azanoradamantane based on spectroscopic analysis, but final confirmation was provided by reductive removal of the benzyl carbamate protecting group to afford the free aminoazanoradamantane $( \pm)-3$, which was identical by proton NMR to the chiral material we had obtained by our previous method. ${ }^{7}$

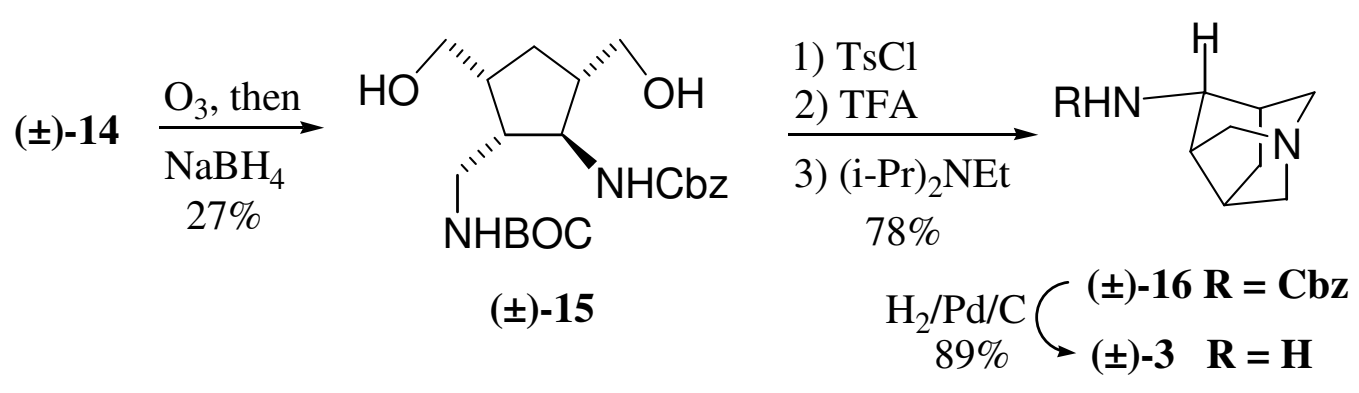

\section{Scheme 4}

The utilization of Yamamoto's racemic acid ester ( \pm )-7 verified the norbornene approach to aminoazanoradamantanes, but we were also still faced with the task of producing non-racemic material. In addition, several steps in the sequence were low yielding and therefore unsuitable for large scale work. Our preliminary attempts at resolution of 5-norbornene-2,3-dicarboxylic acid utilizing chiral bases were not encouraging. Zwanenburg's esterase approach ${ }^{11}$ employing dimethyl 5-norbornene-2,3-dicarboxylate is attractive but affords the wrong enantiomer for the production of SC-52491. We were ultimately attracted to the highly efficient asymmetric Diels-Alder reaction reported by Helmchen ${ }^{2 c, 12}$ to prepare the requisite norbornene to serve as an intermediate for the preparation of chiral aminoazanoradamantanes. The synthetic approach to SC-52491 starting with Helmchen's Diels-Alder methodology was realized as outlined in Schemes 5 and 6.

The chiral norbornene diethyl-(S)-lactate ester 18 was prepared via an uncatalyzed Diels-Alder reaction of the corresponding fumarate diethyl-(S)-lactate ester $\mathbf{1 7}$ and cyclopentadiene according to Helmchen ${ }^{2 c, 12}$ (Scheme 5). The original procedure reported the use of carbon tetrachloride/hexane (1:3) for this Diels-Alder reaction. Since we did not want to use halogenated solvents on a large scale, particularly not carbon tetrachloride, we examined a number of other solvent systems. All other solvent systems examined gave inferior results $(82-90 \%$ d.e.), but we found unexpectedly that utilization of triethylamine as a solvent gave the desired diastereomer 18 in $91-95 \%$ d.e. The Diels-Alder reaction proceeds smoothly on warming the reaction from $-25^{\circ} \mathrm{C}$ to room temperature. Saponification of $\mathbf{1 8}$ and iodolactonization gave the crystalline iodolactone 
(+)-19 in $63 \%$ yield from fumaric ester $\mathbf{1 7}$ and in $99.3 \%$ e.e. by chiral HPLC. The crystallization of (+)-19 is responsible for the very high e.e. beyond what may be expected from the diastereomeric ratio of 18 . The carboxylic acid moiety of (+)-19 was then converted to the primary amide (+)-20 via the acid chloride in 81 96\% yield. A Hofmann-type rearrangement was performed utilizing HTIB (hydroxytosyloxy iodobenzene; Koser's reagent ${ }^{13}$ ) to give the primary amine (+)-21. The reaction was driven to completion with the addition of iodobenzene diacetate, which presumably gives rise to the formation of HTIB in situ. Subsequent tosylation gave the tosylamide (-)-22 in high yield. The iodolactone was reductively cleaved with zinc in acetic acid in almost quantitative yield to give the norbornene carboxylic acid (-)-23.

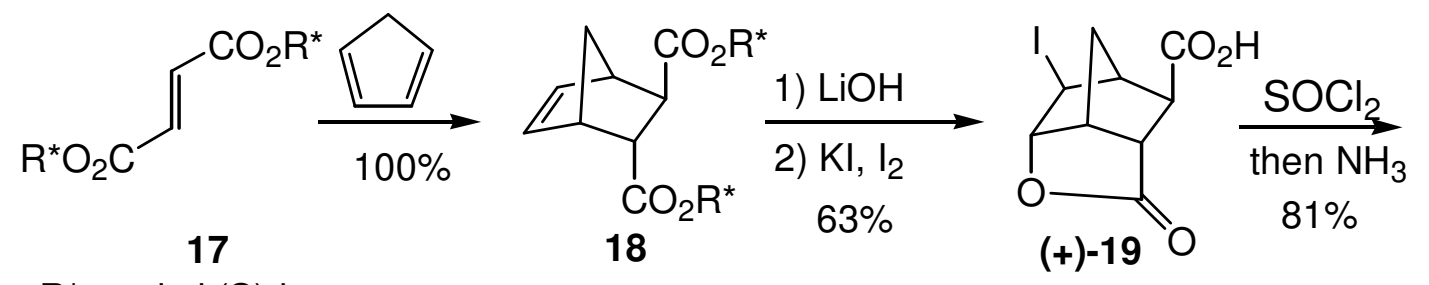

$\mathrm{R}^{*}=$ ethyl (S)-lactate

\section{Scheme 5}
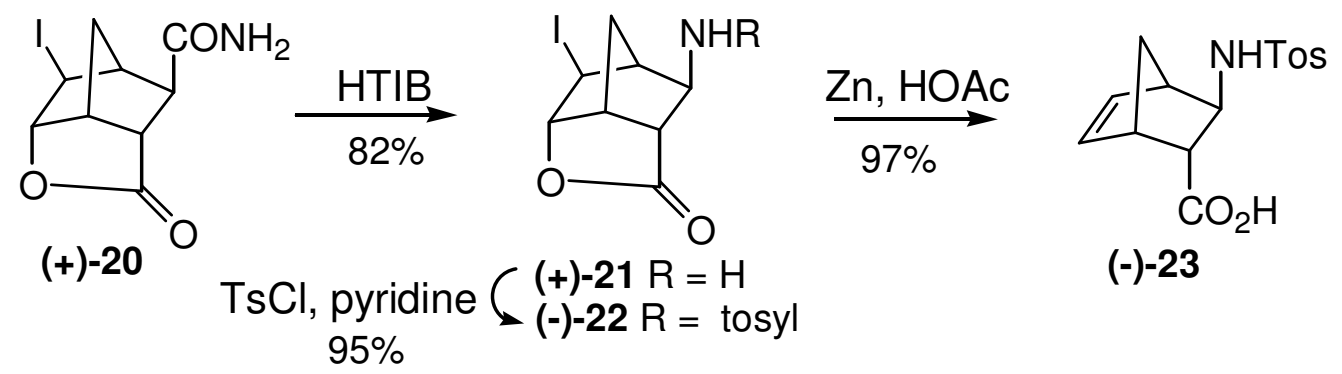

Ozonolysis of (-)-23 with a reductive workup employing sodium borohydride followed by acidification of the crude mixture gave the lactone (+)-24 in quantitative yield (Scheme 6). This procedure employing the free carboxylic acid of (-)-23 to enable direct formation of the lactone was an important factor in obtaining high yields in this ozonolysis, in contrast to the poor yield obtained in the conversion of norbornene $( \pm)-14$ to diol (士)-15. In addition, the resulting $\gamma$-lactone of (+)-24 provided a convenient handle for the incorporation of the amine functionality. Ammonolysis of the lactone gave the primary amide (+)-25. Reduction with borane gave amine 26, which was protected as the tert-butylcarbamate to afford BOC-amine diol (+)-27. Bis-tosylation of the diol was followed directly by removal of the tert-butylcarbamate protecting group with trifluoroacetic acid, and subsequent treatment with diisopropylethylamine in acetonitrile gave the tosyl-protected azanoradamantane $(+)-2^{7}$ in $96 \%$ yield without the need for purification. Deprotection of the tosylamide proceeded cleanly with calcium metal in liquid ammonia. Calcium was chosen over lithium, which we employed earlier, ${ }^{7}$ because of its safer handling characteristics. Coupling of the derived chiral aminoazanoradamantane 3 with 4-amino-5-chloro2-methoxybenzoic acid utilizing carbonyldiimidazole (CDI) as the coupling reagent gave the desired benzamide in $70 \%$ yield, without the use of the acetamide protecting group that was employed in the earlier synthesis. ${ }^{7}$ The $^{2}$ 
product of the coupling was sufficiently pure to use after trituration with a minimum amount of ethyl acetate. The free base was then converted to the crystalline monohydrochloride salt, SC-52491.<smiles>C[13CH2][13CH](C)N</smiles>

$(+)-24$ $(+)-25$

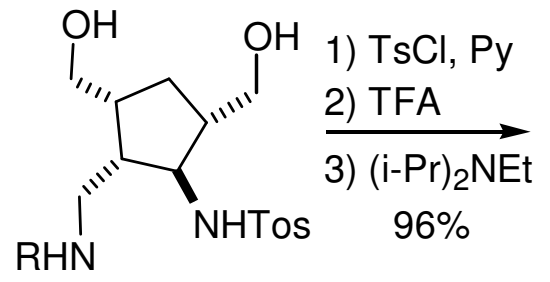

$$
\begin{gathered}
26 \mathrm{R}=\mathrm{H} \\
(+)-27 \mathrm{R}=\mathrm{BOC}
\end{gathered} \quad \begin{gathered}
\mathrm{BOC}-\mathrm{ON} \\
100 \%
\end{gathered}
$$

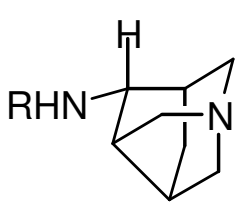

1) 4-amino-5-chloro-2$\underset{\text { methoxybenzoic acid }}{\longrightarrow}$ SC-52491 CDI, DMF (70\%) 2) $\mathrm{HCl}(88 \%)$

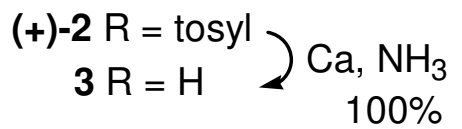

\section{Scheme 6}

\section{Summary}

Utilization of Yamamoto's MAD-catalyzed Diels-Alder methodology provided an initial racemic approach to the key aminoazanoradamantane ( \pm )-3. A scalable asymmetric synthesis of the serotonergic azanoradamantane SC-52491 from inexpensive starting materials via tosyl-protected azanoradamantane (+)-2 and chiral amine $\mathbf{3}$ was then developed employing Helmchen's asymmetric Diels-Alder reaction. In this approach the asymmetric Diels-Alder step assembles all four requisite asymmetric centers for SC-52491 with the proper relative and absolute stereochemistry. Halogenated solvents were eliminated and no chromatography was required in this 15-step sequence which afforded SC-52491 of high enantiomeric purity (>99\% e.e.) and $12 \%$ overall yield.

\section{Experimental Section}

General. All reactions were performed under an atmosphere of argon. Merck silica gel 60 (230-400 mesh) was used for flash chromatography. Merck Kieselgel 60 F254 DC-Fertigplatten (0.25 mm, Art. 5719) were used for TLC. Melting points were determined on a Thomas-Hoover melting point apparatus and are uncorrected. ${ }^{1} \mathrm{H}$ NMR spectra were recorded at $300 \mathrm{MHz}$. Noise-decoupled and APT ${ }^{13} \mathrm{C}$ NMR spectra were recorded at 75 $\mathrm{MHz}$ on a General Electric QE-300 spectrometer. IR spectra were recorded on a Perkin Elmer 685 spectrophotometer. MIR refers to multiple internal reflectance spectroscopy. High-resolution mass spectra were recorded on a Finnigan MAT8430 instrument. Elemental analyses were conducted on a Control Equipment CEC240-XA instrument. 
( \pm )-Methyl 3-[[(phenylmethoxy)carbonyl]amino]-2-bicyclo[2.2.1]hept-5-enecar-boxylate $[( \pm)-8]$. To a solution of carboxylic acid $7^{9}(1.88 \mathrm{~g}, 9.58 \mathrm{mmol})$ and triethylamine $(1.65 \mathrm{~mL}, 1.26 \mathrm{~g}, 12.5 \mathrm{mmol})$ in acetone $(30 \mathrm{~mL})$ at $0^{\circ} \mathrm{C}$ was added ethyl chloroformate $(0.92 \mathrm{~mL}, 1.0 \mathrm{~g}, 9.6 \mathrm{mmol})$ dropwise over several minutes. After the addition was complete the solution was stirred for $1 \mathrm{~h}$ at $0^{\circ} \mathrm{C}$. A solution of sodium azide $(1.87 \mathrm{~g}, 28.7$ mmol) in water $(30 \mathrm{~mL})$ was then added and the reaction was stirred for an additional hour at $0^{\circ} \mathrm{C}$. The solution was then poured in to ice water and the resulting mixture was extracted with ethyl acetate (4 X $50 \mathrm{~mL})$. The combined organic extracts were washed sequentially with sodium bicarbonate and brine and then dried over sodium sulfate. Concentration gave a residue which was dissolved in dry benzene $(50 \mathrm{~mL})$ and heated under reflux for $1.5 \mathrm{~h}$. Benzyl alcohol $(2.07 \mathrm{~g}, 19 \mathrm{mmol})$ was then added and heating under reflux was continued for and additional $2.5 \mathrm{~h}$. Concentration gave a pale yellow oil which was crystallized from $\mathrm{Et}_{2} \mathrm{O} / \mathrm{hexane}$ to give the title compound $( \pm)-8(2.1 \mathrm{~g}, 73 \%)$ as colorless crystals: $\mathrm{mp} 73-76^{\circ} \mathrm{C}$; IR (MIR) $3362,1727,1688,1538 \mathrm{~cm}^{-1} ;{ }^{1} \mathrm{H}$ NMR (300 MHz) $\delta$ 7.40-7.28 (5H, m), 6.25-6.18 (1H, m), 6.12-6.06 (1H, m), $5.11(2 \mathrm{H}, \mathrm{s}), 4.85(1 \mathrm{H}$, br s), 3.94-3.84 (1H, m), $3.65(3 \mathrm{H}, \mathrm{s}), 3.14(1 \mathrm{H}, \mathrm{br} \mathrm{s}), 2.85(1 \mathrm{H}, \mathrm{br} \mathrm{s}), 2.55(1 \mathrm{H}, \mathrm{t}, \mathrm{J}=4 \mathrm{~Hz}), 1.65(1 \mathrm{H}, \mathrm{d}, \mathrm{J}=9.6 \mathrm{~Hz})$, $1.56(1 \mathrm{H}, \mathrm{d}, \mathrm{J}=9 \mathrm{~Hz}) ;{ }^{13} \mathrm{C} \mathrm{NMR}\left(75 \mathrm{MHz}, \mathrm{CDCl}_{3}\right) \delta 173.1,155.7,136.3,135.8,135.4128 .3,128.0,127.9,66.6$, 55.2, 52.4, 51.5, 48.8, 46.6, 44.8. MS (EI) calcd for $\mathrm{C}_{17} \mathrm{H}_{19} \mathrm{NO}_{4}$ 301; found 301. Anal calcd for $\mathrm{C}_{17} \mathrm{H}_{19} \mathrm{NO}_{4} \mathrm{C}_{\text {, }}$ 67.76; H, 6.36; N, 4.65. Found C, 67.59; H, 6.46; N, 4.63.

(士)-Phenylmethyl N-[3-(hydroxymethyl)bicyclo[2.2.1]hept-5-en-2-yl]carbamate [( \pm )-9]. To a solution of methyl ester $( \pm)-8$ in dry THF $(1 \mathrm{~mL})$ and absolute methanol $(0.031 \mathrm{~mL}, 0.76 \mathrm{mmol})$ was added a solution of lithium borohydride $(0.37 \mathrm{~mL}$ of a $2 \mathrm{M}$ solution in THF, $0.76 \mathrm{mmol})$ and the solution was stirred for $2 \mathrm{~h}$ at $\mathrm{rt}$ before quenching with $1 \mathrm{~N} \mathrm{HCl}(3 \mathrm{~mL})$. The resulting mixture was extracted with ethyl acetate $(3 \mathrm{X} 15 \mathrm{~mL})$ and the combined extracts were washed sequentially with sodium bicarbonate, water and brine, and then dried over sodium sulfate. Concentration gave a colorless oil which was purified by chromatography on silica gel eluting with 50/50 ethyl acetate/hexane to give carbinol ( \pm )-9 $(84 \mathrm{mg}, 84 \%)$ as a colorless oil which crystallized on standing: mp $111-113^{\circ} \mathrm{C}$; IR (MIR) 3398, 3250, 1690, $1563 \mathrm{~cm}^{-1} ;{ }^{1} \mathrm{H}$ NMR $\left(300 \mathrm{MHz}, \mathrm{CDCl}_{3}\right) \delta 7.40-7.30(5$ H, m), 6.18-6.08 (2 H, m), 5.37 (1H, br s), $5.11(1 \mathrm{H}, \mathrm{d}, \mathrm{J}=12 \mathrm{~Hz}), 5.04(1 \mathrm{H}, \mathrm{d}, \mathrm{J}=12 \mathrm{~Hz}), 4.04$ (1H, br s), 3.62-3.52 (1H, m), $3.23(1 \mathrm{H}, \mathrm{t}, \mathrm{J}=10 \mathrm{~Hz}), 3.17-3.10(1 \mathrm{H}, \mathrm{m}), 2.79(1 \mathrm{H}, \mathrm{s}) 2.73(1 \mathrm{H}, \mathrm{s}), 2.03-1.95(1 \mathrm{H}, \mathrm{m}), 1.57$ $(2 \mathrm{H}, \mathrm{s}) ;{ }^{13} \mathrm{C} \mathrm{NMR}\left(75 \mathrm{MHz}, \mathrm{CDCl}_{3}\right) \delta 156.9,136.5,136.3,134.9,128.5,128.2,66.8,65.6,56.0,53.1,48.5$, 46.9, 44.1. $\mathrm{MH}+(\mathrm{CI})$ calcd for $\mathrm{C}_{16} \mathrm{H}_{19} \mathrm{NO}_{3} 274$, found 274. Anal calcd for $\mathrm{C}_{16} \mathrm{H}_{19} \mathrm{NO}_{3} .015 \mathrm{H}_{2} \mathrm{O} \mathrm{C}, 69.62 ; \mathrm{H}, 7.05$; N, 5.07. Found C, 69.81; H, 7.05; N, 5.07.

Mesylate ( \pm )-10 To a solution of alcohol $( \pm)-9(611 \mathrm{mg}, 2.23 \mathrm{mmol})$, triethylamine $(339 \mathrm{mg}, 3.35 \mathrm{mmol})$, and DMAP (14 mg, $0.11 \mathrm{mmol})$ in dry methylene chloride at $-78^{\circ} \mathrm{C}$ was added methanesulfonyl chloride $(384 \mathrm{mg}$, $3.35 \mathrm{mmol})$ via syringe. After $3 \mathrm{~d}$ at $-30^{\circ} \mathrm{C}$ the suspension was diluted with additional methylene chloride (40 
$\mathrm{mL}$ ) and the resulting solution was washed successively with $1 \mathrm{~N} \mathrm{HCl}$, water, and brine. After drying over sodium sulfate the solution was concentrated to the desired mesylate $( \pm)-\mathbf{1 0}$ as an oil which solidified to a

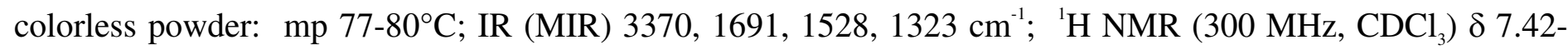
$7.29(5 \mathrm{H}, \mathrm{m}), 6.22$ (1H, dd, J = 5.7, $2.8 \mathrm{~Hz}), 6.18(1 \mathrm{H}, \mathrm{dd}, \mathrm{J}=5.7,2.7 \mathrm{~Hz}), 5.10(2 \mathrm{H}, \mathrm{s}), 4.94-4.82(1 \mathrm{H}, \mathrm{m}), 4.35$ $(1 \mathrm{H}, \mathrm{dd}, \mathrm{J}=8.6,6.1 \mathrm{~Hz}), 3.91(1 \mathrm{H}, \mathrm{t}, \mathrm{J}=10 \mathrm{~Hz}), 3.17-3.08(1 \mathrm{H}, \mathrm{m}), 2.98$ (4H, br s), $2.78(1 \mathrm{H}, \mathrm{s}), 2.12(1 \mathrm{H}$, ddt, $\mathrm{J}=9.6,6.4,3.5 \mathrm{~Hz}), 1.72(1 \mathrm{H}, \mathrm{dd}, \mathrm{J}=9,1.2 \mathrm{~Hz}), 1.55(1 \mathrm{H}, \mathrm{d}, \mathrm{J}=9 \mathrm{~Hz}) ;{ }^{13} \mathrm{C} \mathrm{NMR}\left(75 \mathrm{MHz} \mathrm{CDCl}_{3}\right) \delta$ $155.9,136.4,136.2,135.5,128.5,128.1,128.0,72.1,66.8,54.7,48.8,48.6,46.6,43.2,37.2$. MS MH+ (CI) calcd for $\mathrm{C}_{17} \mathrm{H}_{21} \mathrm{NO}_{5} \mathrm{~S} 352$, found 352. Anal. calcd for $\mathrm{C}_{17} \mathrm{H}_{21} \mathrm{NO}_{5} \mathrm{~S} .1 / 4 \mathrm{H}_{2} \mathrm{O} \mathrm{C}, 57.37 ; \mathrm{H}, 6.09 ; \mathrm{N}, 3.94$. Found $57.58 ; \mathrm{H}, 6.14 ; \mathrm{N}, 3.84$.

( \pm )-Phenylmethyl N-[3-formylbicyclo[2.2.1]hept-5-en-2-yl]carbamate [( \pm )-12]. To a solution of alcohol ( \pm )9 (404 mg, $1.48 \mathrm{mmol}$ ) and triethylamine (450 mg, $4.44 \mathrm{mmol})$ in dry DMSO (5 mL) was added sulfur trioxidepyridine complex (706 mg, $4.44 \mathrm{mmol})$. The pale yellow solution was stirred at $\mathrm{rt}$ for 15 minutes, then poured into ice water $(50 \mathrm{~mL})$. The mixture was extracted with ethyl acetate $(3 \mathrm{X} 50 \mathrm{~mL})$ and the combined organic extracts were washed successively with water $(4 \times 30 \mathrm{~mL})$ and brine and then dried over sodium sulfate. Concentration gave the title aldehyde $( \pm)-12(380 \mathrm{mg}, 95 \%)$ as a colorless solid: $\mathrm{mp}$ 75-79 ${ }^{\circ} \mathrm{C}$. IR (MIR) 3347, 1705, 1686, $1536 \mathrm{~cm}^{-1}$; ${ }^{1} \mathrm{H}$ NMR (300 MHz, $\left.\mathrm{CDCl}_{3}\right), \delta 9.59(1 \mathrm{H}, \mathrm{s}), 7.43-7.29(5 \mathrm{H}, \mathrm{m}), 6.12(2 \mathrm{H}, \mathrm{m}), 5.11(2 \mathrm{H}$, s), 4.92 (1H, br s), 3.89-3.80 (1H, m), 3.21-3.17 (1H, m), 2.93-2.85 (1H, m), $2.57(1 \mathrm{H}, \mathrm{q}, \mathrm{J}=3 \mathrm{~Hz}), 1.69(1 \mathrm{H}$, $\mathrm{dd}, \mathrm{J}=8.9,0.95 \mathrm{~Hz}), 1.61(1 \mathrm{H}, \mathrm{d}, \mathrm{J}=8.9 \mathrm{~Hz}) ;{ }^{13} \mathrm{C} \mathrm{NMR}\left(125 \mathrm{MHz}, \mathrm{CDCl}_{3}\right) \delta 202.6,155.9,136.2,135.8,135.6$, 66.9, 61.4, 53.4, 48.6, 46.7, 43.9. MS (CI) $\mathrm{MH}+$ calcd for $\mathrm{C}_{16} \mathrm{H}_{17} \mathrm{NO}_{3}$ 272, found 272. Anal calcd for $\mathrm{C}_{16} \mathrm{H}_{17} \mathrm{NO}_{3} .0 .2 \mathrm{H}_{2} \mathrm{O}$ C, 69.90; H, 6.38; N. 5.10. Found C, 70.05; H, 6.68; N, 5.08.

( \pm )-Phenylmethyl N-[3-(aminomethyl)bicyclo[2.2.1]hept-5-en-2-yl]carbamate [( \pm )-13]. To a solution of the aldehyde $( \pm)-12(243 \mathrm{mg}, 0.89 \mathrm{mmol})$ in methanol $(9 \mathrm{~mL})$ at $\mathrm{rt}$ was added ammonium acetate $(690 \mathrm{mg}, 8.9$ mmol) followed by borane-pyridine $(83 \mathrm{mg}, 0.89 \mathrm{mmol})$. After stirring for $2.5 \mathrm{~h}$ at $\mathrm{rt}$ the solution was concentrated in vacuo to give a residue which was treated with $20 \%$ aqueous potassium carbonate $(15 \mathrm{~mL})$ and extracted with chloroform ( 3 X $15 \mathrm{~mL})$. The combined extracts were washed with water and brine and then dried over sodium sulfate. Concentration gave a residue which was chromatographed on silica gel eluting with 4/96 EtOH $\left(\mathrm{NH}_{3}\right) /$ ethyl acetate to give the amine $( \pm)-13(30 \mathrm{mg}, 12 \%)$ as a colorless glass. ${ }^{1} \mathrm{H} \mathrm{NMR}(300 \mathrm{MHz}$, $\left.\mathrm{CDCl}_{3}\right) \delta$ 7.42-7.28 (5 H, m), 6.20-6.03 (1 H, m), $6.10(1 \mathrm{H}, \mathrm{dd}, \mathrm{J}=5.6,2.7 \mathrm{~Hz}), 5.09$ (2 H, s), 5.05 (1 H, d, J = $3.3 \mathrm{~Hz}), 3.12(1 \mathrm{H}, \mathrm{d}, \mathrm{J}=5.0 \mathrm{~Hz}), 2.82(1 \mathrm{H}$, br s), $2.74(1 \mathrm{H}$, br s), $2.65(1 \mathrm{H}, \mathrm{dd}, \mathrm{J}=12,7.4 \mathrm{~Hz}), 2.52(1 \mathrm{H}$, dd, $\mathrm{J}=12,7.6 \mathrm{~Hz}), 1.67(1 \mathrm{H}, \mathrm{m}), 1.63(1 \mathrm{H}, \mathrm{dd}, \mathrm{J}=8.8,1.1 \mathrm{~Hz}), 1.50(1 \mathrm{H}, \mathrm{d}, \mathrm{J}=8.9 \mathrm{~Hz}), 1.39(2 \mathrm{H}, \mathrm{s})$. 
bamate [( \pm )-14]. To a solution of the amine $( \pm)-13(300 \mathrm{mg}, 1.10 \mathrm{mmol})$ in dry THF (30 mL) was added ditert-butyldicarbonate $(280 \mathrm{mg}, 1.28 \mathrm{mmol})$. After stirring for $24 \mathrm{~h}$ at $\mathrm{rt}$ the solution was concentrated in vacuo to give a residue which was chromatographed on silica gel eluting with 30/70 ethyl acetate/hexane to afford the title BOC-protected amine $( \pm)-\mathbf{1 4}(359 \mathrm{mg}, \mathbf{8 8 \%})$ as a colorless solid: mp 116-117 ${ }^{\circ} \mathrm{C}$; IR (MIR) 3340, 1685, 1522, $1258 \mathrm{~cm}^{-1} ;{ }^{1} \mathrm{H}$ NMR (300 MHz, $\left.\mathrm{CDCl}_{3}\right) \delta$ 7.40-7.28 (5 H, m), 6.15 (2 H, m), 5.50 (1 H, br s), 5.10 (2 H, s), 4.89 (1 H, d, J = $5 \mathrm{~Hz}), 3.24-3.07$ (2 H, m), 2.79 (2 H, br s), 2.74 (1 H, s), 1.86 (1 H, br s), 1.63 (1 H, d, J = 9

$\mathrm{Hz}), 1.51(1 \mathrm{H}, \mathrm{d}, \mathrm{J}=9 \mathrm{~Hz}), 1.44(9 \mathrm{H}, \mathrm{s}) .{ }^{13} \mathrm{C} \mathrm{NMR}\left(75 \mathrm{MHz}, \mathrm{CDCl}_{3}\right) \delta 156.2,156.1,136.3,136.0,135.3$, 128.5, 128.1, 66.8, 56.0, 50.1, 49.9, 48.8, 46.8, 44.2, 44.0, 28.3. HRMS M+1 calc for $\mathrm{C}_{21} \mathrm{H}_{28} \mathrm{~N}_{2} \mathrm{O}_{4} 373.2127$, found 373.2138. Anal calcd for $\mathrm{C}_{21} \mathrm{H}_{28} \mathrm{~N}_{2} \mathrm{O}_{4} \mathrm{C}, 67.72 ; \mathrm{H}, 7.58 ;$ N. 7.52. Found C, 67.59; H, 7.67; N, 7.41.

\section{(士)-1,1-Dimethylethyl N-[1,4-bis(hydroxymethyl)-3-[[(phenylmethoxy)carbonyl]-amino]cyclopentan-2-yl]-}

carbamate $[( \pm)-15]$. Ozone was bubbled through a solution of BOC-amine $( \pm)-14(36 \mathrm{mg}, 0.097 \mathrm{mmol})$ in 5:1 $\mathrm{CH}_{2} \mathrm{Cl}_{2} / \mathrm{MeOH}$ at $-78^{\circ} \mathrm{C}$ until a blue color persisted $(3 \mathrm{~min})$. Argon was then bubbled through the solution until the blue color disappeared. Sodium borohydride $(18 \mathrm{mg}, 0.48 \mathrm{mmol})$ was added to the solution at minus $78^{\circ} \mathrm{C}$ and the reaction was allowed to warm up to $\mathrm{rt}$ over $1 \mathrm{~h}$. After stirring for an additional $16 \mathrm{~h}$ at $\mathrm{rt}$, brine $(10 \mathrm{~mL})$ was added and the reaction was extracted with methylene chloride (4 X $10 \mathrm{~mL})$. The combined organic extracts were washed successively with water and brine and then dried over sodium sulfate. Concentration gave a colorless oil which was purified by preparative thin-layer chromatography on silica gel eluting (2 X) with 4/96 $\mathrm{EtOH} / \mathrm{ethyl}$ acetate to give the diol $( \pm)-15(11 \mathrm{mg}, 27 \%)$ as colorless crystals: $\mathrm{mp} 142-144^{\circ} \mathrm{C}$; IR (MIR) 3288, 1691, 1667, $1541 \mathrm{~cm}^{-1} ;{ }^{1} \mathrm{H}$ NMR $\left(\mathrm{CDCl}_{3}\right) \delta$ 7.39-7.27 (5 H, m), $5.57(1 \mathrm{H}, \mathrm{br} \mathrm{s}), 5.28(1 \mathrm{H}, \mathrm{br} \mathrm{s}), 5.13(1 \mathrm{H}, \mathrm{d}, \mathrm{J}=$ $13 \mathrm{~Hz}), 5.07$ (1 H, d, J = $13 \mathrm{~Hz}), 3.64$ (2 H, m), 3.58-3.48 (2 H, m), 3.48-3.25 (2 H, m), 3.18-3.07 (1 H, m), 2.59 (1 H, br s), 2.40-2.26 (1 H, m), 2.17-1.76 (4 H, m), $1.43(9 \mathrm{H}, \mathrm{s}), 1.28-1.13(1 \mathrm{H}, \mathrm{m}) ;{ }^{13} \mathrm{C} \mathrm{NMR}(400 \mathrm{MHz}$, $\left.\mathrm{CDCl}_{3}\right) \delta 157.3,156.4,141.4,136.4,128.5,128.2,128.1,105.0,79.3,67.1,63.8,63.0,56.3,50.5,48.1,47.7$, 39.5, 39.4, 28.9, 28.5. MS M+1 calcd for $\mathrm{C}_{21} \mathrm{H}_{32} \mathrm{~N}_{2} \mathrm{O}_{6}$, 409.2339; found 409.2364. Anal. Calcd for $\mathrm{C}_{21} \mathrm{H}_{32} \mathrm{~N}_{2} \mathrm{O}_{6} .1 / 4 \mathrm{H}_{2} \mathrm{O}$ C, 61.07; H, 7.93; N, 6.78. Found C, 61.02; H, 7.67; N, 6.73.

\section{(士)-Phenylmethyl N-(hexahydro-2,5 $\beta$-methano-1H-3a $\alpha, 6 a \alpha-c y c l o p e n t a[c] p y r r o l-4 \alpha-y l) c a r b a m a t e \quad[( \pm)-$}

16]. To a solution of diol $( \pm)-15(18 \mathrm{mg}, 0.044 \mathrm{mmol})$ in pyridine $(0.6 \mathrm{~mL})$ at $0^{\circ} \mathrm{C}$ was added solid $p$ toluenesulfonyl chloride $(45 \mathrm{mg}, 0.24 \mathrm{mmol})$ with stirring. After dissolution was complete the solution was allowed to stand at $0^{\circ} \mathrm{C}$ for $23 \mathrm{~h}$. The solution was then poured onto ice $(15 \mathrm{~g})$ and extracted with ethyl acetate (3 X $10 \mathrm{~mL})$. The combined organic extracts were washed successively with water (3X $30 \mathrm{~mL})$ and brine $(30$ $\mathrm{mL})$ and then dried over sodium sulfate. Concentration gave the di-tosylate $(23 \mathrm{mg})$ as a colorless oil which was treated directly with freshly-distilled trifluoroacetic acid $(0.5 \mathrm{~mL})$ at $\mathrm{rt}$. After stirring for $15 \mathrm{~min}$ the 
solution was concentrated in vacuo to give a residue which was redissolved in acetonitrile $(1 \mathrm{~mL})$ and treated with diisopropylethylamine (31 mg, $0.24 \mathrm{mmol}$ ). After $21 \mathrm{~h}$ at $\mathrm{rt}$ the solution was concentrated in vacuo to give a residue which was treated with aqueous $15 \%$ potassium carbonate $(1 \mathrm{~mL})$ and then extracted with chloroform ( 3 X $15 \mathrm{~mL}$ ). The combined organic extracts were washed successively with water and brine and then dried over sodium sulfate. Concentration then gave the title azanoradamantane $( \pm)-\mathbf{1 6}(9.2 \mathrm{mg}, 78 \%)$ as colorless crystals. IR (MIR) 3171, 1703, 1454, 1259, $1247 \mathrm{~cm}^{-1}$; ${ }^{1} \mathrm{H}$ NMR $\left(\mathrm{CDCl}_{3}\right) \delta$ 7.39-7.27 (5 H, m), 5.08 (2 H, s), $4.71(1 \mathrm{H}, \mathrm{br} \mathrm{s}), 3.97(1 \mathrm{H}, \mathrm{d}, \mathrm{J}=6 \mathrm{~Hz}), 3.12(1 \mathrm{H}, \mathrm{d}, \mathrm{J}=11 \mathrm{~Hz}), 2.99(1 \mathrm{H}, \mathrm{dd}, \mathrm{J}=11,3 \mathrm{~Hz}), 2.95-2.68(4 \mathrm{H}$, m), 2.55-2.40 (2 H, m), $2.08(1 \mathrm{H}, \mathrm{s}), 1.98-1.85(1 \mathrm{H}, \mathrm{m}), 1.80(1 \mathrm{H}, \mathrm{d}, \mathrm{J}=12 \mathrm{~Hz}) ;{ }^{13} \mathrm{C}$ NMR $\left(400 \mathrm{MHz}, \mathrm{CDCl}_{3}\right)$ $\delta$ 128.6, 128.1, 105.0, 66.7, 65.2, 63.8, 57.6, 45.8, 45.6, 42.6, 38.8, 37.7. MS calcd for $\mathrm{C}_{16} \mathrm{H}_{20} \mathrm{~N}_{2} \mathrm{O}_{2}: 272.1525$; found 272.1524 .

( \pm )-2,53-methano-1H-3a $\alpha, 6 a \alpha-c y c l o p e n t a[c] p y r r o l-4 \alpha$-amine $[( \pm)-3]$ from Cbz-derivative $( \pm)-16$. To a suspension of $10 \%$ palladium on carbon ( $2 \mathrm{mg}$ ) in ethanol was added a solution of benzyl carbamate $( \pm)-16(9.2$ $\mathrm{mg}, 0.034 \mathrm{mmol})$ in methanol $(0.4 \mathrm{~mL})$ at $\mathrm{rt}$. The suspension was then stirred under an atmosphere of hydrogen $(1 \mathrm{~atm})$ for $1 \mathrm{~h}$. Removal of the catalyst by filtration and concentration of the filtrate gave the free amine ( \pm )-3 (4.2 mg, 89\%) as a waxy semisolid which was identical by ${ }^{1} \mathrm{H}$ NMR to material prepared previously.

bis-Lactate fumarate diester (17). Fumaryl chloride (100 g, $0.653 \mathrm{~mol})$ and ethyl (S)-lactate (147 mL, 1.3 mol) were dissolved in 1.6 liters of toluene with $400 \mathrm{mg}$ of hydroquinone. The reaction mixture was heated between $80^{\circ} \mathrm{C}$ and $85^{\circ} \mathrm{C}$ for $18 \mathrm{~h}$, sweeping the $\mathrm{HCl}$ from the mixture with a gentle stream of nitrogen. The reaction mixture was then cooled to $-25^{\circ} \mathrm{C}$. A second portion of ethyl (S)-lactate was added. Triethylamine (191 $\mathrm{mL} ; 1.37 \mathrm{~mol}$ ) was added to the reaction mixture, keeping the temperature below $-10^{\circ} \mathrm{C}$. The reaction mixture was stirred for one hour, allowing the reaction mixture to warm to room temperature. The reaction mixture was washed successively with 2 X $200 \mathrm{~mL} 2 \mathrm{~N} \mathrm{HCl}, 200 \mathrm{~mL}$ water, 4 X $200 \mathrm{~mL} 2 \mathrm{~N} \mathrm{NaOH}$, then 3 X $250 \mathrm{~mL}$ brine. The organic layer was dried over $\mathrm{MgSO}_{4}$ and concentrated. The residue was diluted to 1 liter with $15 \%$ EtOAc/hexane and then filtered through $600 \mathrm{~g}$ of silica, eluting with $8 \times 500 \mathrm{~mL}$ fractions of 15\% EtOAc/hexane to yield $186 \mathrm{~g}$ (90.3\%) of the desired diester $\mathbf{1 7}$ as an oil, which was used without further purification. ${ }^{1} \mathrm{H}$ NMR $\left(\mathrm{CDCl}_{3}\right) \delta 7.0(2 \mathrm{H}, \mathrm{s}), 5.19(2 \mathrm{H}, \mathrm{q}, \mathrm{J}=11 \mathrm{~Hz}), 4.22(4 \mathrm{H}, \mathrm{q}, \mathrm{J}=12 \mathrm{~Hz}), 1.57(6 \mathrm{H}, \mathrm{d}, \mathrm{J}=11$ $\mathrm{Hz}), 1.3(6 \mathrm{H}, \mathrm{t}, \mathrm{J}=12 \mathrm{~Hz})$.

Diels-Alder adduct (18). In a modification of Helmchen's ${ }^{2 c}$ procedure, di-(ethyl (S)-lactate) fumarate 17 (352 $\mathrm{g}, 1.11 \mathrm{~mol})$ was dissolved in 5.5 liters of $\mathrm{Et}_{3} \mathrm{~N}$ and cooled to $0^{\circ} \mathrm{C}$. Cyclopentadiene $(140 \mathrm{~mL} ; 1.71 \mathrm{~mol})$ was added within ten minutes, and the reaction was mildly exothermic. The temperature reached $8^{\circ} \mathrm{C}$ before dropping again to $0^{\circ} \mathrm{C}$. The reaction mixture was allowed to warm to room temperature and stir for $18 \mathrm{~h}$. 
Concentration afforded norbornene $18(450.7 \mathrm{~g}, 100 \%)$ as an oil and used without further purification. The ratio of the two diastereomers was determined by HPLC [Supelco LC-18 DB; 65/35 MeCN/ $\mathrm{H}_{2} \mathrm{O}$ ] to be $92.8: 7.2$ for $(2 \mathrm{R}, 3 \mathrm{R}) /(2 \mathrm{~S}, 3 \mathrm{~S})$.

(+)-Hexahydro-6 $\beta$-iodo-2-oxo-3 $\alpha$ R,5 $\alpha$-methano-2H-3a $\beta, 6 a \beta$ cyclopenta[b]furan-7S-carboxylic acid [(+)19]. The saponification of diester $18(471.5 \mathrm{~g}, 1.17 \mathrm{~mol})$ to give the corresponding diacid was carried out as described by Helmchen, ${ }^{2 c}$ and conversion of the diacid to the iodolactone (+)-19 ${ }^{2 c}$ was followed with a modified workup using THF/EtOAc (1:1) for the extractions to afford $227.5 \mathrm{~g}$ (63\% from fumarate 17) of the iodolactone (+)-19. Anal. Calcd for $\mathrm{C}_{9} \mathrm{H}_{9} \mathrm{IO}_{4}:$ C, 35.09; H, 2.94; I, 41.19. Found: C, 35.28; H, 2.92; I, 41.23. $[\alpha]_{\mathrm{D}}+54.4^{\circ}$ $(\mathrm{c}=1.0$ in $\mathrm{EtOH})$

(+)-Hexahydro-6 $\beta$-iodo-2-oxo-3 $\alpha$ R,5 $\alpha$-methano-2H-3a $\beta, 6 a \beta$ cyclopenta[b]furan-7S-carboxamide [(+)-20]. Iodolactone (+)-19 (227.5 g, $0.73 \mathrm{~mol})$ was suspended in $\mathrm{SOCl}_{2}(132 \mathrm{~mL})$ and gently warmed to reflux, where complete solution occurred. The reaction mixture was concentrated to remove the excess $\mathrm{SOCl}_{2}$. The residue was dissolved in toluene $(350 \mathrm{~mL})$ and slowly added to a mixture of liquid $\mathrm{NH}_{3}(85 \mathrm{~mL})$ and 2 liters of THF cooled to $-30^{\circ} \mathrm{C}$. The reaction mixture was stirred for $0.5 \mathrm{~h}$ before adding $500 \mathrm{~mL}$ of $\mathrm{H}_{2} \mathrm{O}$. The layers were separated and the organic layer was washed with brine $(500 \mathrm{~mL})$, dried over $\mathrm{MgSO}_{4}$ and concentrated to an oil. The oil slowly crystallized when triturated with EtOAc. The solid was filtered and washed with EtOAc and dried in vacuum to yield $181.5 \mathrm{~g}(81 \%)$ of primary amide (+)-20 as a white solid: DSC $165.65^{\circ} \mathrm{C} ;[\alpha]_{\mathrm{D}}+34.5^{\circ}$ $(\mathrm{c}=1.0 \mathrm{in} \mathrm{EtOH})$; IR (KBr) 3470, 3423, 3362, 3187, 1769, $1681 \mathrm{~cm}^{-1} ;{ }^{1} \mathrm{H} \mathrm{NMR}\left(400 \mathrm{MHz}, \mathrm{CDCl}_{3}\right) \delta 5.62(1 \mathrm{H}$, br s), $5.45(1 \mathrm{H}, \mathrm{br} \mathrm{s}), 5.14(1 \mathrm{H}, \mathrm{d}, \mathrm{J}=5.0 \mathrm{~Hz}), 3.87(1 \mathrm{H}, \mathrm{d}, \mathrm{J}=2.6 \mathrm{~Hz}), 3.21(1 \mathrm{H}, \mathrm{m}), 3.07(1 \mathrm{H}, \mathrm{dd}, \mathrm{J}=4.8$ $\mathrm{Hz}, 1.1 \mathrm{~Hz}), 2.93(1 \mathrm{H}, \mathrm{s}), 2.69(1 \mathrm{H}, \mathrm{s}), 2.33(1 \mathrm{H}, \mathrm{dd}, \mathrm{J}=11.9,1.3 \mathrm{~Hz}), 2.24(1 \mathrm{H}, \mathrm{dd}, \mathrm{J}=11.9,2.1 \mathrm{~Hz}) ;{ }^{13} \mathrm{C}$ NMR (400 MHz, d ${ }_{6}$-DMSO) $\delta 177.9,171.2,88.8,51.2,51.0,46.1,41.5,35.2,35.1,28.1$. Anal. Calcd for $\mathrm{C}_{9} \mathrm{H}_{10} \mathrm{INO}_{3}$ : C, 35.20; H, 3.28; I, 41.32; N, 4.56. Found: C, 35.40; H, 3.26; I, 41.20; N, 4.50.

(+)-Hexahydro-6 $\beta$-iodo-2-oxo-3 $\alpha \mathrm{R}, 5 \alpha$-methano-2H-3a $\beta, 6 a \beta$-cyclopenta[b]furan-7S-amine, 4-methylbenzenesulfonate [(+)-21]. Primary amide (+)-20 (30.0 g, $96.0 \mathrm{mmol})$ was dissolved in $\mathrm{CH}_{3} \mathrm{CN}(500 \mathrm{~mL})$. HTIB (hydroxy(tosyloxy)iodobenzene, $42 \mathrm{~g}, 0.108 \mathrm{~mol}$ ) was added to the reaction mixture and stirring was continued. The mixture thickened to a solid mass within 5 minutes. The mixture was slowly warmed to reflux where the solid mass became mobile again. The reaction mixture was allowed to cool to $35^{\circ} \mathrm{C}$. IBDA (iodobenzene diacetate, $15.4 \mathrm{~g}, 48 \mathrm{mmol}$ ) was added and the mixture thickened again. The mixture was reheated to $65^{\circ} \mathrm{C}$ where the solid mass became mobile again. The reaction mixture was stirred $18 \mathrm{~h}$, filtered, washed with $\mathrm{CH}_{3} \mathrm{CN}$ and suction dried to yield $35.4 \mathrm{~g}(82 \%)$ of primary amine $(+)-21:[\alpha]_{\mathrm{D}}+32.8(\mathrm{c}=1.09, \mathrm{EtOH}) ;[\alpha]_{365}$ +137.5 (c= 1.09, EtOH); IR (KBr) 3470, 3361, 1767, $1682 \mathrm{~cm}^{-1} ;{ }^{1} \mathrm{H} \mathrm{NMR}\left(400 \mathrm{MHz}, \mathrm{CDCl}_{3}\right) \delta 5.13(1 \mathrm{H}, \mathrm{d}, \mathrm{J}=$ 
$2 \mathrm{~Hz}) ; 3.88(1 \mathrm{H}, \mathrm{d}, \mathrm{J}=1 \mathrm{~Hz}) ; 3.21(1 \mathrm{H}, \mathrm{t}, \mathrm{J}=1 \mathrm{~Hz}) ; 3.07(1 \mathrm{H}, \mathrm{d}, \mathrm{J}=1.5 \mathrm{~Hz}) ; 2.93(1 \mathrm{H}, \mathrm{s}) ; 2.49(1 \mathrm{H}, \mathrm{s}) ; 2.33(1 \mathrm{H}$, $\mathrm{d}, \mathrm{J}=4 \mathrm{~Hz}) ; 2.22(1 \mathrm{H}, \mathrm{d}, \mathrm{J}=4 \mathrm{~Hz}) ;{ }^{13} \mathrm{C} \mathrm{NMR}\left(400 \mathrm{MHz}, \mathrm{CDCl}_{3}\right) \delta 177.8,171.2,88.8,51.2,51.0,41.5,35.1,28.1$. Anal. Calcd for $\mathrm{C}_{15} \mathrm{H}_{18} \mathrm{INO}_{5} \mathrm{~S}:$ C, 39.92; H, 4.02; N, 3.10; S, 7.11. Found: C, 39.96; H, 4.04; N, 2.90; S, 7.38. For the monotosylate salt: $[\mathrm{a}]_{\mathrm{D}}+30.0(\mathrm{c}=1.04, \mathrm{EtOH}) ; \quad[\mathrm{a}]_{365}+98.6(\mathrm{c}=1.04, \mathrm{EtOH}) ; \mathrm{IR}(\mathrm{KBr}) 3435,2997,1792$ $\mathrm{cm}^{-1}$; ${ }^{1} \mathrm{H}$ NMR (400 MHz, d $\left.-\mathrm{DMSO}\right) \delta 7.49(2 \mathrm{H}, \mathrm{d}, \mathrm{J}=4 \mathrm{~Hz}) ; 7.12(2 \mathrm{H}, \mathrm{d}, \mathrm{J}=4 \mathrm{~Hz}) ; 5.16(1 \mathrm{H}, \mathrm{d}, \mathrm{J}=3 \mathrm{~Hz}) ; 5.12$ $(1 \mathrm{H}, \mathrm{d}, \mathrm{J}=2 \mathrm{~Hz}) ; 4.11(1 \mathrm{H}, \mathrm{d}, \mathrm{J}=1 \mathrm{~Hz}) ; 3.66(1 \mathrm{H}, \mathrm{s}) ; 3.30(1 \mathrm{H}, \mathrm{t}, \mathrm{J}=1 \mathrm{~Hz}) ; 2.76(1 \mathrm{H}, \mathrm{s}) ; 2.62(1 \mathrm{H}, \mathrm{d}, \mathrm{J}=2 \mathrm{~Hz})$; $2.30(3 \mathrm{H}, \mathrm{s}) ; 2.29(1 \mathrm{H}, \mathrm{d}, \mathrm{J}=7 \mathrm{~Hz}) ; 2.12(1 \mathrm{H}, \mathrm{d}, \mathrm{J}=7 \mathrm{~Hz}) .{ }^{13} \mathrm{C}$ NMR (400 MHz, d $\left.-\mathrm{DMSO}\right) \delta 175.0,145.6$, $137.5,128.0,125.4,87.3,53.1,50.8,45.9,44.0,32.9,24.9,20.7$.

\section{(-)-N-(3a $\beta, 6 a \beta$-hexahydro-6 $\beta$-iodo-2-oxo-3 $\alpha$ R,5 $\alpha$-methano-2H-cyclopenta[b]furan-7S-yl)-4-methylben-}

zenesulfonamide [(-)-22]. The tosylate salt of (+)-21 (1.0 g, $2.2 \mathrm{mmol})$ was dissolved in pyridine (5.0 mL). pToluenesulfonyl chloride $(476 \mathrm{mg}, 2.5 \mathrm{mmol})$ was added and the reaction mixture stirred for $2 \mathrm{~h}$ and concentrated. The residue was partitioned between THF and brine. The organic layer was washed subsequently with dilute $\mathrm{HCl}$ and dilute $\mathrm{K}_{2} \mathrm{CO}_{3}$, and dried over $\mathrm{MgSO}_{4}$, and concentrated. The residue was placed on $50 \mathrm{~g}$ of silica and eluted with $50 \mathrm{~mL}$ of 1:1 EtOAc/heptane. The solution was concentrated to an oil which slowly crystallized to yield $913 \mathrm{mg}(95 \%)$ of tosylamide (-)-22. $[\alpha]_{\mathrm{D}}-65.6^{\circ}$ (c = 1.0 in EtOH); IR (KBr) 3433, 3238, $1763 \mathrm{~cm}^{-1} ;{ }^{1} \mathrm{H}$ NMR (400 MHz, $\left.\mathrm{CDCl}_{3}\right) \delta 7.79(2 \mathrm{H}, \mathrm{d}, \mathrm{J}=4 \mathrm{~Hz}) ; 7.73(2 \mathrm{H}, \mathrm{d}, \mathrm{J}=4 \mathrm{~Hz}) ; 5.16(1 \mathrm{H}, \mathrm{d}, \mathrm{J}=3 \mathrm{~Hz})$; $5.04(1 \mathrm{H}, \mathrm{d}, \mathrm{J}=2 \mathrm{~Hz}) ; 3.49(1 \mathrm{H}, \mathrm{d}, \mathrm{J}=1 \mathrm{~Hz}) ; 3.12(1 \mathrm{H}, \mathrm{t}, \mathrm{J}=1 \mathrm{~Hz}, \mathrm{~J}=3 \mathrm{~Hz}) ; 2.72(1 \mathrm{H}, \mathrm{s}) ; 2.43(3 \mathrm{H}, \mathrm{s}) ; 2.31(1 \mathrm{H}$, $\mathrm{d}, \mathrm{J}=7 \mathrm{~Hz}) ; 2.11(1 \mathrm{H}, \mathrm{d}, \mathrm{J}=7 \mathrm{~Hz}) .{ }^{13} \mathrm{C} \mathrm{NMR}\left(400 \mathrm{MHz}, \mathrm{CDCl}_{3}\right) \delta 175.38,144.4,136.1,130.2,127.3,87.8$, 58.0, 53.4, 47.3, 45.7, 34.6, 24.9, 21.6. Anal. Calcd for $\mathrm{C}_{15} \mathrm{H}_{16} \mathrm{INO}_{4} \mathrm{~S}$ : C, 41.58; H, 3.72; N, 3.23; S, 7.40. Found: C, 41.49; H, 3.79; N, 3.28; S, 7.77.

(-)-3R-[[(4-Methylphenyl)sulfonyl]amino]-bicyclo[2.2.1]hept-5-ene-2 $\alpha \mathbf{R} \quad$ carboxylic $\quad$ acid $\quad[(-)-23]$. Iodolactone (-)-22 (27.0 g, $0.062 \mathrm{~mol})$ and $\mathrm{Zn}^{\circ}(16.2 \mathrm{~g}, 0.249 \mathrm{~mol})$ were combined in glacial acetic acid (100 $\mathrm{mL}$ ) and refluxed for $0.5 \mathrm{~h}$. The reaction mixture was cooled and filtered through celite. The filtrate was concentrated and the residue suspended in water, and the resulting crystalline solid was filtered, washed with water and dried to yield $18.4 \mathrm{~g}(97 \%)$ of carboxylic acid (-)-23 as a white solid. $[\alpha]_{\mathrm{D}}-24.9^{\circ}(\mathrm{c}=1.0$, EtOH); $[\alpha]_{365}-46.8^{\circ}(\mathrm{c}=1.0, \mathrm{EtOH}) ; \operatorname{IR}(\mathrm{KBr}) 3921,3788,1707 \mathrm{~cm}^{-1} ;{ }^{1} \mathrm{H}$ NMR $\left(300 \mathrm{MHz}, \mathrm{d}_{6}-\mathrm{DMSO}\right) \delta 7.85(2 \mathrm{H}, \mathrm{d}, \mathrm{J}=$ $4 \mathrm{~Hz}) ; 7.69$ (2H, d, J= $4 \mathrm{~Hz}) ; 6.08-5.94(2 \mathrm{H}, \mathrm{m}, \mathrm{J}=2 \mathrm{~Hz}) ; 3.39$ (1H, s); 3.24 - 3.30 (1H, m); 2.76 (1H, s); 2.99 $(1 \mathrm{H}, \mathrm{s}) ; 2.61(1 \mathrm{H}, \mathrm{t}, \mathrm{J}=2 \mathrm{~Hz}) 2.30(3 \mathrm{H}, \mathrm{s}) ; 2.58(1 \mathrm{H}, \mathrm{s}) ; 2.48(3 \mathrm{H}, \mathrm{s}) ; 1.72(1 \mathrm{H}, \mathrm{d}, \mathrm{J}=2 \mathrm{~Hz}) ; 1.40(1 \mathrm{H}, \mathrm{d}, \mathrm{J}=2 \mathrm{~Hz})$. ${ }^{13} \mathrm{C}$ NMR (300 MHz, d - DMSO) $\delta 173.4,142.4,138.3,135.7,135.4,129.4,126.5,56.1,50.9,48.4,46.5,44.6$, 20.9. Anal. Calcd for $\mathrm{C}_{15} \mathrm{H}_{17} \mathrm{NSO}_{4}$ : C, 56.95; H, 5.73; N, 4.43; S, 10.14. Found: C, 57.08; H, 5.42; N, 4.36; S, 10.33 . 


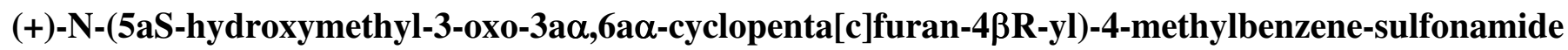
$[(+)-24]$.

Ozone was bubbled through a solution of carboxylic acid (-)-23 (2.0 g, $6.5 \mathrm{mmol})$ in ethyl acetate/methanol (24 $\mathrm{mL} ; 5: 1)$ at $-78^{\circ} \mathrm{C}$ until a light blue color persisted. Caution should be exercised when utilizing ozone in flammable solvents to avoid fire. After stirring for an additional $0.5 \mathrm{~h}$ at $-78^{\circ} \mathrm{C}$, argon was bubbled through the solution for $25 \mathrm{~min}$ to remove excess ozone. To the colorless solution was then added sodium borohydride pellets $(1.07 \mathrm{~g}, 32.5 \mathrm{mmol})$ at $-78^{\circ} \mathrm{C}$. The reaction mixture allowed to warm to room temperature and stirred for $40 \mathrm{~h}$. To the reaction mixture was added 3 drops of methyl orange/methanol indicator followed by a solution of $2 \mathrm{~N} \mathrm{HCl} /$ methanol to give a light pink color and the reaction was then stirred for $72 \mathrm{~h}$ at room temperature. The mixture was concentrated in vacuo. To the residue was added brine $(35 \mathrm{~mL})$ and the mixture was extracted with ethyl acetate $(3 \times 50 \mathrm{~mL})$. The combined extracts were washed successively with water and brine, dried over $\mathrm{MgSO}_{4}$, filtered and concentrated to give the desired lactone (+)-24 as a waxy white solid $(2.01 \mathrm{~g}, 100 \%):[\alpha]_{\mathrm{D}}$ $=+1.4^{\circ}\left(\mathrm{c}=0.70\right.$ in $\left.\mathrm{CH}_{3} \mathrm{OH}\right) ;$ IR $(\mathrm{MIR}) 3453,3219,1753,1156 \mathrm{~cm}^{-1} ;{ }^{1} \mathrm{H}$ NMR $\left(\mathrm{CD}_{3} \mathrm{OD}\right) \delta 7.82(2 \mathrm{H}, \mathrm{d}, \mathrm{J}=8$ $\mathrm{Hz}), 7.34(2 \mathrm{H}, \mathrm{d}, \mathrm{J}=8 \mathrm{~Hz}), 4.27(1 \mathrm{H}, \mathrm{dd}, \mathrm{J}=9,6 \mathrm{~Hz}), 4.06(1 \mathrm{H}, \mathrm{d}, \mathrm{J}=9 \mathrm{~Hz}) ; 3.68(1 \mathrm{H}, \mathrm{dd}, \mathrm{J}=7,3 \mathrm{~Hz}), 3.50$ $(1 \mathrm{H}, \mathrm{dd}, \mathrm{J}=10,4 \mathrm{~Hz}), 3.36(1 \mathrm{H}, \mathrm{dd}, \mathrm{J}=11,6 \mathrm{~Hz}), 2.97(1 \mathrm{H}, \mathrm{m}), 2.78(1 \mathrm{H}, \mathrm{dd}, \mathrm{J}=9,3 \mathrm{~Hz}), 2.40(3 \mathrm{H}, \mathrm{s}) ; 2.09$ $(2 \mathrm{H}, \mathrm{m}), 1.25(1 \mathrm{H}, \mathrm{m}) ;{ }^{13} \mathrm{C}\left(\mathrm{CD}_{3} \mathrm{OD}\right) \delta 178.4,142.8,138.5,128.8,126.6,70.8,60.8,57.8,46.9,46.6,38.9,32.2$, 19.7 .

(+)-1a,4a-bis(hydroxymethyl)-3b-[[(4-methylphenyl)sulfonyl]amino] cyclopentane-2a-carboxamide (25). A solution of lactone $24(2.0 \mathrm{~g}, 6.5 \mathrm{mmol})$ in methanol in a Parr Shaker was pressurized with ammonia gas to $50 \mathrm{psi}$ for $4 \mathrm{~h}$ at $60^{\circ} \mathrm{C}$. The solution was then filtered through celite and concentrated in vacuo to give a white solid. The solid was recrystallized from ethanol to give primary amide 25 (1.52 g, $72 \%)$ : $\mathrm{mp}=191.5$ $192.5^{\circ} \mathrm{C} ; \quad[\alpha]_{\mathrm{D}}=+46.8^{\circ} \quad\left(\mathrm{c}=1.10\right.$ in $\left.\mathrm{CH}_{3} \mathrm{OH}\right) ;$ IR $(\mathrm{MIR}) 3453,3219,1753,1156 \mathrm{~cm}^{-1} ;{ }^{1} \mathrm{H} \mathrm{NMR}(300 \mathrm{MHz}$ $\left.\mathrm{CD}_{3} \mathrm{OD}\right) \delta 7.70(2 \mathrm{H}, \mathrm{d}, \mathrm{J}=7.5 \mathrm{~Hz}) 7.33(2 \mathrm{H}, \mathrm{d}, 7.5 \mathrm{~Hz}) 3.66(3 \mathrm{H}, \mathrm{m}), 3.66(1 \mathrm{H}, \mathrm{dd}, \mathrm{J}=6.0,2.0 \mathrm{~Hz}) 3.42(1 \mathrm{H}$, $\mathrm{dd}, \mathrm{J}=7.5,2.5 \mathrm{~Hz}), 2.70(1 \mathrm{H}, \mathrm{m}), 2.42(3 \mathrm{H}, \mathrm{s}), 2.41(1 \mathrm{H}, \mathrm{m}), 2.37(1 \mathrm{H}, \mathrm{m}), 1.99(1 \mathrm{H}, \mathrm{m}), 1.25(1 \mathrm{H}, \mathrm{m}) ;{ }^{13} \mathrm{C}$ (100.6 MHz, CD 3 OD) $\delta 177.6,144.6,139.5,130.7,120.2,64.3,64.0,60.0,54.8,50.0,44.5,33.0,21.5$; Anal. Calcd for $\mathrm{C}_{15} \mathrm{H}_{22} \mathrm{~N}_{2} \mathrm{SO}_{5} \cdot 0.5 \mathrm{H}_{2} \mathrm{O}: \mathrm{C}, 51.27 ; \mathrm{H}, 6.60 ; \mathrm{N}, 7.97$. Found: C, 51.16; H, 6.53; N, 7.96.

Amine 26. To a suspension of primary amide 25 (1.0 g, $2.9 \mathrm{mmol})$ in THF (100 mL) was added dropwise a $1 \mathrm{M}$ solution of borane-THF over $20 \mathrm{~min}$. The reaction mixture stirred for $1 \mathrm{~h}$ at $\mathrm{rt}$ followed by refluxing for $18 \mathrm{~h}$. The reaction mixture was cooled to $0^{\circ} \mathrm{C}$ and $15 \%$ aqueous $\mathrm{HCl}(100 \mathrm{~mL})$ was added. The reaction was then allowed to warm up to stir at $\mathrm{rt}$ for $14 \mathrm{~h}$ The solution was then concentrated in vacuo to a white foam which was dissolved in water $(10 \mathrm{~mL})$ and then treated with $1 \mathrm{~N} \mathrm{NaOH}(10 \mathrm{~mL})$. The solution was stirred for $3 \mathrm{~h}$, saturated with $\mathrm{NaCl}$, and extracted with THF. The combined extracts were dried over $\mathrm{MgSO}_{4}$ and then concentrated in vacuo to give oil. The oil was passed through a pad of silica eluting with ethyl acetate followed 
by $20 \% \mathrm{CH}_{3} \mathrm{OH}\left(\mathrm{NH}_{3}\right) / \mathrm{THF}$ to give the free amine $26(700 \mathrm{mg}, 74 \%): \quad{ }^{1} \mathrm{H}\left(300 \mathrm{MHz}, \mathrm{CD}_{3} \mathrm{OD}\right) \delta 7.76(2 \mathrm{H}, \mathrm{d}, \mathrm{J}$ $=9.0 \mathrm{~Hz}), 7.38(2 \mathrm{H}, \mathrm{d}, \mathrm{J}=9.0 \mathrm{~Hz}), 3.48(2 \mathrm{H}, \mathrm{m}), 3.26(1 \mathrm{H}, \mathrm{d}, \mathrm{J}=4 \mathrm{~Hz}), 3.05(2 \mathrm{H}, \mathrm{m}), 2.72(2 \mathrm{H}, \mathrm{d}, \mathrm{J}=4 \mathrm{~Hz})$, $2.41(2 \mathrm{H}, \mathrm{s}), 2.31(1 \mathrm{H}, \mathrm{m}), 1.12(1 \mathrm{H}, \mathrm{m}), 1.84(1 \mathrm{H}, \mathrm{m}), 1.96(2 \mathrm{H}, \mathrm{m}) ;{ }^{13} \mathrm{C}\left(100.6 \mathrm{MHz}, \mathrm{CD}_{3} \mathrm{OD}\right) \delta 143.7,139.5$, $129.8,127.0,62.8,62.7,58.3,49.9,40.0,39.2,29.6,20.6$. This amine was protected directly as the BOC derivative without further purification.

\section{(+)-1,1-dimethylethyl-N-[[1 $\alpha, 4 \alpha$-bis(hydroxymethyl)-3 $\beta$-[[(4-methylphenyl)sulfonyl]amino]-cyclopentan-}

2 $\alpha$-yl]methyl]carbamate (27). Thus, to a solution of the amine 26 (570 $\mathrm{mg}, 1.73 \mathrm{mmol})$ and triethyl amine $(0.45 \mathrm{~mL}, 1.9 \mathrm{mmol})$ in acetone/water $(10 \mathrm{~mL})$ was added BOC-ON (2-(tert-butoxycarbonyloxyimino)-2phenylacetonitrile; $470 \mathrm{mg}, 2.9 \mathrm{mmol}$ ) and the reaction stirred for $18 \mathrm{~h}$ at $\mathrm{rt}$. The solution was extracted with ethyl acetate $(3 \mathrm{X})$. The combined extracts were washed successively with water and brine, dried over $\mathrm{MgSO}_{4}$, filtered, and concentrated in vacuo to an oil. The oil was passed through a pad of silica gel eluting with ethyl acetate to give the BOC-protected amine $27(740 \mathrm{mg}, 100 \%)$. [ $\alpha]_{\mathrm{D}}+22.4$ (c=0.157, $\left.\mathrm{CHCl}_{3}\right)$; IR (MIR) 3384, 3291,1684 (str), 1516, $1156 \mathrm{~cm}^{-1} ;{ }^{1} \mathrm{H}$ NMR $\left(300 \mathrm{~Hz}, \mathrm{CD}_{3} \mathrm{OD}\right) \delta 7.77(2 \mathrm{H}, \mathrm{d}, \mathrm{J}=8.0 \mathrm{~Hz}) 7.37(2 \mathrm{H}, \mathrm{d}, \mathrm{J}=8.0$ Hz), 3.49 (2H, m), 3.35 (2H, m), $3.19(1 \mathrm{H}, \mathrm{m}), 3.12(1 \mathrm{H}, \mathrm{t}, \mathrm{J}=7.5 \mathrm{~Hz}), 2.92(2 \mathrm{H}, \mathrm{m}), 2.24(1 \mathrm{H}, \mathrm{m}), 2.41(3 \mathrm{H}, \mathrm{s})$, $1.92(1 \mathrm{H}, \mathrm{m}), 2.04(1 \mathrm{H}, \mathrm{m}), 1.42(9 \mathrm{H}, \mathrm{s}) ;{ }^{13} \mathrm{C} \mathrm{NMR} \delta\left(100.6 \mathrm{~Hz}, \mathrm{CD}_{3} \mathrm{OD}\right)$ 143.6, 139.5, 129.7, 127.1, 78.5, 63.1, 62.4, 58.6, 48.4, 40.7, 38.5, 29.7, 27.8, 20.5. Anal Calcd for $\mathrm{C}_{20} \mathrm{H}_{32} \mathrm{~N}_{2} \mathrm{SO}_{6}: 1 / 2 \mathrm{H}_{2} \mathrm{O}: \mathrm{C}, 54.90 ; \mathrm{H}, 7.60 ; \mathrm{N}, 6.40$. Found: C, 54.91; H, 7.47; N, 6.07.

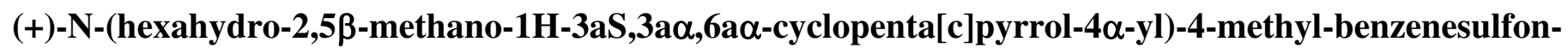

amide [(+)-2]. To a solution of BOC-amine diol (+)-27 (207 mg, $0.484 \mathrm{mmol})$ in dry pyridine $(2.4 \mathrm{~mL})$ at $20^{\circ} \mathrm{C}$ was added $p$-toluenesulfonyl chloride $(369 \mathrm{mg}, 1.94 \mathrm{mmol}$ ) with stirring. After dissolution was complete the solution was allowed to stand at $0^{\circ} \mathrm{C}$ for $21 \mathrm{~h}$. The reaction was then poured onto ice and extracted with ethyl acetate (3X). The combined extracts were washed successively with water $(5 X)$ and brine and then dried over sodium sulfate. Concentration gave a colorless foam $(357 \mathrm{mg})$. The foam was dissolved in trifluoroacetic acid $(5 \mathrm{~mL})$ and allowed to stand for $15 \mathrm{~min}$ at $\mathrm{rt}$ after which time the reaction was concentrated under vacuum. The resulting residue was dissolved in acetonitrile $(10 \mathrm{~mL})$ and treated with diisopropylethylamine $(433 \mathrm{mg}$, $3.35 \mathrm{mmol}$ ). After 4 days at $\mathrm{rt}$ the pale yellow solution was warmed to $46^{\circ} \mathrm{C}$ for $2 \mathrm{~h}$. Concentration gave a residue which was treated with $4 \mathrm{~N} \mathrm{KOH} /$ presaturated with $\mathrm{NaCl}(5 \mathrm{~mL})$ and extracted with ethyl acetate $(5 \mathrm{X})$. The combined extracts were washed with water $(2 \mathrm{X})$ and brine and dried over sodium sulfate. Concentration then gave the tosylamide azanoradamantane $(+)-2(134 \mathrm{mg}, 96 \%)$ as a pale yellow solid: $\mathrm{mp} 203-205^{\circ} \mathrm{C} ;[\alpha]_{\mathrm{D}}=$ $+3.0^{\circ}\left(\mathrm{c}=0.76\right.$ in $\left.\mathrm{CHCl}_{3}\right)$. The proton NMR was identical to the material prepared via the previously described route. ${ }^{7}$ 


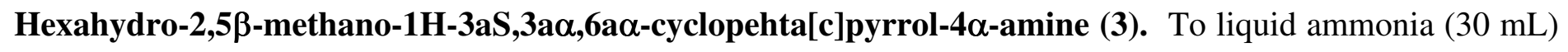
at $-33^{\circ} \mathrm{C}$ was added a solution of tosylamide (+)-2 (539 $\left.\mathrm{mg}, 1.84 \mathrm{mmol}\right)$ in THF (7 mL). Calcium metal (319 $\mathrm{mg}, 7.96 \mathrm{mmol}$ ) was added in three portions over $5 \mathrm{~min}$. After $30 \mathrm{~min}$ the dark blue reaction was quenched with addition of solid ammonium chloride $(985 \mathrm{mg}, 18.4 \mathrm{mmol})$. Concentration gave a residue which was treated with $4 \mathrm{~N} \mathrm{KOH}$-presaturated with $\mathrm{NaCl}(9.2 \mathrm{~mL})$. The suspension was filtered through celite and the solid was washed with THF. The filtrate was extracted with THF (7X) and the combined THF rinses and extracts were dried over sodium sulfate. Concentration gave chiral aminoazanoradamantane $3(0.29 \mathrm{~g}, 100 \%)$ as a colorless waxy solid. The proton NMR was identical to the material prepared via the previously described route. ${ }^{7}$

\section{(+)-4-amino-5-chloro-N-(hexahydro-2,5 $\beta$-methano-1H-3aS,3a $\alpha, 6 a \alpha-c y c l o p e n t a[c]-p y r r o l-4 \alpha-y l)-2-$}

methoxybenzamide, (free base of SC-52491). To a solution of 4-amino-5-chloro-2-methoxybenzoic acid (371 $\mathrm{mg}, 1.84 \mathrm{mmol})$ in DMF (1.8 mL) was added carbonyldiimidazole (298 mg, $1.84 \mathrm{mmol})$. After $1 \mathrm{~h}$ at $\mathrm{rt} \mathrm{a}$ solution of the chiral aminoazanoradamantane 3 derived from (+)-2 (255 mg, $1.84 \mathrm{mmol})$ in DMF (1.9 mL) was added and the resulting pale yellow solution was stirred at $\mathrm{rt}$ for $24 \mathrm{~h}$. Concentration under vacuum at $36^{\circ} \mathrm{C}$ gave a yellow solid which was triturated with ethyl acetate $(5 \mathrm{~mL})$, filtered, and rinsed with cold $\left(0^{\circ} \mathrm{C}\right)$ ethyl acetate $(1.5 \mathrm{~mL})$. The solid was then dried in vacuo at $52^{\circ} \mathrm{C}$ to give the free base of $\mathbf{S C - 5 8 2 4 1}$ as a pale yellow solid (413 mg, 70\%), which was converted directly to the hydrochloride salt.

\section{(+)-4-amino-5-chloro-N-(hexahydro-2,5 $\beta$-methano-1H-3aS,3a $\alpha, 6 a \alpha-c y c l o p e n t a[c]-p y r r o l-4 \alpha-y l)-2-$}

methoxybenzamide, monohydrochloride (SC-52491). To a solution of free base of SC-52491 (343 mg, 1.04 $\mathrm{mmol})$ in $95 \%$ ethanol $(10 \mathrm{~mL})$ was added ethanolic $\mathrm{HCl}$ [prepared from acetyl chloride $(75 \mathrm{mg}, 1.07 \mathrm{mmol})$ and $95 \%$ ethanol $(0.5 \mathrm{~mL})]$. The solution was allowed to stand at $0^{\circ} \mathrm{C}$ for $24 \mathrm{~h}$. Filtration of the resulting crystalline solid and rinsing with cold $\left(0^{\circ} \mathrm{C}\right) 95 \%$ ethanol $(1.5 \mathrm{~mL})$ gave the desired material which was dried at $63^{\circ} \mathrm{C}$ in vacuo for $16 \mathrm{~h}$ to afford the hydrochloride SC-52491 $(337 \mathrm{mg}, 88 \%)$ as an off-white powder. $[\alpha]_{\mathrm{D}}=$ $+7.1^{\circ}(\mathrm{c}=0.23, \mathrm{MeOH})$. Anal. Calcd for $\mathrm{C}_{16} \mathrm{H}_{20} \mathrm{~N}_{3} \mathrm{O}_{2} \mathrm{Cl} . \mathrm{HCl} . \mathrm{H}_{2} \mathrm{O}$ : C, 51.07; H, 6.16; N, 11.17; Cl, 18.84 . Found: $\mathrm{C}, 50.80 ; \mathrm{H}, 6.16 ; \mathrm{N}, 11.00 ; \mathrm{Cl}, 18.54$. The proton NMR was identical to the material prepared via the previously described route.

\section{Acknowledgments}

Professors Paul A Grieco, George Fleet and Peter Beak are gratefully acknowledged for valuable discussions and advice. 


\section{References}

1. Shinkai, I., Pure Appl. Chem. 1997, 69, 453-458.

2. a) Whiting, A., "Asymmetric Diels-Alder Reactions", in Adv. Asymmetric Synth; Stephenson, G. Richard, Ed.; Chapman \& Hall: London, 1996, pp. 126-145. b) Kagan, H. B.; Riant, O. Chem. Rev. 1992, 92, 1007-1019. c) Helmchen, G.; Karge, R.: Weetman, J. "Asymmetric Diels-Alder Reactions with Chiral Enoates as Dienophiles”, in Modern Synthetic Methods 1986; Scheffold, R., Ed.; Springer-Verlag Berlin Heidelberg, 1986, Vol. 4, pp. 261-306. For the application of asymmetric Diels-Alder reactions in the efficient preparation of pharmaceutically important molecules, see for example: d) Martinelli, M. J. J. Org. Chem. 1990, 55, 5065-73. e) Hansen, M. M.; Bertsch, C. F.; Harkness, A. R.; Huff, B. E.; Hutchison, D. R.; Khau, V. V.; LeTourneau, M. E.; Martinelli, M. J.; Misner, J. W.; Peterson, B. C.; Rieck, J. A.; Sullivan, K. A.; Wright, I. G. J. Org. Chem. 1998, 63, 775-85.

3. a) Flynn, D. L.; Becker, D. P.; Spangler, D. P.; Nosal, R.; Gullikson, G. W.; Moummi, C.; and Yang, D. -C. Bioorg. Med. Chem. Lett. 1992, 2, 1613-8. b) Becker, D. P.; Goldstin, B.; Gullikson, G. W.; Loeffler, R.; Moormann, A.; Moummi, C.; Nosal, R.; Spangler, D.; Villamil, C. I.; Yang, D. -C.; Zabrowski, D. L.; Flynn, D. L. in "Perspectives in Receptor Research", ed. D. Giardina et. al. , Pharmacochemistry Library, Vol 24, Elsevier Science B. V.: Amsterdam, 1996, pp. 99-120.

4. Baxter, G. S.; Craig, D. A.; Clarke, D. E.; Naunyn-Schmiedeberg's Arch. Pharmacol. 1991, 343, 439.

5. The assay of Kilpatrick was employed using ${ }^{3} \mathrm{H}-\mathrm{GR} 65630$ as the radioligand with male rat cortical tissue. Kilpatrick, G. J.; Jones, B. J.; Tyers, M.B.; Nature, 1987, 330, 746.

6. SC-52491 exhibits $\mathrm{IC}_{50}$ values $>10,000 \mathrm{nM}$ for 5-HT - like, 5-HT $\mathrm{HT}_{2}$ dopamine $\mathrm{D}_{1}$ and $\mathrm{D}_{2}, \alpha_{1}-, \alpha_{2}-$, and $\beta$ adrenergic receptors).

7. Becker, D. P.; Nosal, R.; Zabrowski, D. L.; Flynn, D. L. Tetrahedron 1997, 53, 1-20.

8. Becker, D. P.; Flynn, D. L. Tet. Lett. 1993, 34, 2087-90; Becker, D. P.; Flynn, Tetrahedron 1993, 49, 5047-54.

9. Maruoka, K.; Saito, S.; Yamamoto, H. J. Am. Chem. Soc. 1992, 114, 1089-90.

10. Meth-Cohn, O. J. Chem. Soc., Chem. Commun. 1986, 695-697.

11. Klunder, A. J. H.; van Gastel, F. J. C.; Zwanenburg, B. Tet. Lett. 1988, 29, 2697-2700.

12. a) Hartmann, H.; Abdel Hady, A. F.; Sartor, K.; Weetman, J.; Helmchen, G. Angew. Chem. 1987, 99, 11881189; b) Hartmann, H.; Fattah Abdel Hady, A.; Sartor, K.; Weetman, J.; Helmchen, G. Angew. Chem. Int. Ed. Engl. 1987, 26, 1143-1145. c) Helmchen, G.; Poll, T.; Hartmann, H.; Karge, R. DE 3702084 A1 (1987); CAN 108:111830. d) Helmchen, G.; Goeke, A.; Lauer, G.; Urmann, M.; Fries, J.; Angew. Chem. Int. Ed. Engl. 1990, 29, 1024-5.

13. Lazbin, I. M.; Koser, G. F.; J. Org. Chem. 1986, 51, 2669-71. 